\title{
Acts 17:27 - "that they might feel after him and find ..."
}

\author{
Sjef van Tilborg ${ }^{1}$ \\ Katholieke Universiteit Nijmegen, The Netherlands \\ Research Associate: Department of New Testament Studies \\ University of Pretoria
}

\begin{abstract}
The aim of this article is to investigate the allusion to the possibility of touching God ( $\left.\psi \eta \lambda \alpha \phi \sigma^{\prime} \omega\right)$ in Paul's Areopagus speech (Acts 17:27). The article aims at assessing the Lukan notion of God's nearness in space and time. The Areopagus discourse is investigated against the background of its imbeddednes in the holistic context of Acts. God's nearness is studied in light of common Hellenistic parallel epiphanies. It focuses on dream types in Acts, epiphanies of Jesus, epiphanies of God, and in conclusion the expression "filled with the Spirit".
\end{abstract}

\section{INTRODUCTION}

After having been blinded by Odysseus with a glowing stick, the Cyclops goes to sit at the entrance of the cave, with outstretched hands, hoping that, groping, he might at least still catch some of the men and kill them $(\mathrm{Od} 9,416)$. He is now a blind man stretching out his hands to find out by feeling, groping and touching what the surrounding world looks like. In this famous scene from the Odyssey, the same word is used as that in Luke many centuries later, in the speech Paul delivers at the Areopagus in Athens ( $\psi \eta \lambda \alpha \phi \alpha \dot{\omega} \omega)$.

What is at stake here is the possibility of touching God. Because the combination "touching" and "God" is considered by many exegetes improbable, a more spiritual meaning is often suggested for the word. Instead of "groping, touching" one would have

\footnotetext{
1 Prof Dr Sjef van Tilborg participates as associate in the research project "Biblical theology and Hermeneutics", directed by Prof Dr Andries G van Aarde, Department of New Testament Studies, Faculty of Theology, University of Pretoria.
} 
to think of something like "investigative searching". 2 One also wonders what the object of this searching is. Does it have something to do with a more intellectual search: the acknowledgment of the existence of God, the knowledge of who God is; the knowledge of the nature and the being of God? Or does it have to do with a search in which, in the first place, feeling and wanting are involved: to want to know what plan God has for me, for us, for people, and what he asks of people; a being orientated towards coming to an experience of God? This difference in objects of knowledge is related to a contrast between Hellenistic, philosophical thinking and biblical, more person-orientated, thinking.

It is a contrast which could also be used to describe the history of the interpretation of the Areopagus speech in the last century. Karl Barth has played a decisive role in this regard. He has had a potent influence on the choice and the assessment of the study by M Dibelius, Paulus auf dem Areopag, ${ }^{3}$ that has itself been of great significance to subsequent scholars. For this reason, his influence is evident in the more recent studies of $\mathrm{H} \mathrm{J} \mathrm{Klauck}{ }^{4}$ and K Löning 5 .

In Magie und Heidentum in der Apostelgeschichte des Lukas, $\mathrm{H} \mathrm{J}$ Klauck wonders whether Luke might here have betrayed the Christian image of God and man for the sake of a strategic advantage. He answers this question: "Ganz sicher nicht. Er (=Lukas) übernimmt im Grunde nur das Sprachgewand, nicht die (stoisch-philosophischen) Inhalte und nicht die denkerischen Voraussetzungen" ( $p$ 106). Luke could very well have used the same words but not with the same meaning. ${ }^{6}$

$\mathrm{K}$ Löning thinks that the Areopagus speech should be read in an ironic sense. There is a big difference between the communication of Paul with his (narrative) audience in Athens and the communication between Luke and his readers. The audience

\footnotetext{
2 See, for example, C K Barrett, Acts, II, 845 which refers also to the scene Cyclops scene in the Odyssey. I presume that he too found the reference in Liddell-Scott-Jones.

${ }^{3}$ Aufsätze zur Apostelgeschichte, Göttingen, 1961/4 (1951), 29-70; in the English translation "Paul on the Areopagus", in Studies in the Acts of the Apostles, London, 1956.

${ }^{4}$ Magie und Heidentum in der Apostelgeschichte des Lukas, Stuttgart, 1996.

5 "Das Gottesbild der Apostelgeschichte im Spannungsfeld von Frühjudentum und Fremdreligionen", in HJ Klauck (Hrsg), Monotheismus und Christologie: Zur Gottesfrage im hellenistischen Judentum und im Urchristentum, Freiburg, 1992, 88- I17.

${ }^{6}$ I do not know how one should understand this in terms of the philosophy of language. In my opinion, it is an extremely strong form of nominalism: words as the cloths of meaning.
} 
in Athens does not want to understand Paul and laughs at him. The readers, on the other hand, have to take seriously the Christian closing statements about the resurrection of Jesus and the certainty of the final judgment. The distinction between these two forms of communication sees to it "da $\beta$ der Leser nicht auf den Gedanken kommen kann, die real existierende, hellenistische Philosophie sei die Vorschule des christlichen Glaubens" ( $p$ 109). ${ }^{7}$ For this is naturally what is at stake. The Hellenistic philosophy would be an expression of natural theology - and it should be repudiated and rejected in the strongest terms. Only Christian theology is acceptable, conceived as a theology of revelation, as a knowing about God's desires and demands, as the revelation of God in God's power and majesty.

Time and again one sees the danger that the speech at the Areopagus would be a Fremdkörper in the entirety of Acts: a speech that makes (too much) use of stoic ideas. One could then try to show that a number of these lines of thought can be recognized also in the Bible and thus be rightfully called biblical. ${ }^{8}$ But in the middle of the speech the quotation from Aratus, "being then God's offspring", appears very provocative, preceded as it is by the even more Hellenistic phrase, "in him we live and move and are". This is indeed so Hellenistic-pantheistic that more drastic measures of interpretation are called for. "Iı Him" could also mean "through Him" in Greek, in which case the phrase seems again to fit perfectly in the Judeo-Christian creation theology. ${ }^{9}$ This is once again an attempt to keep Luke free of Hellenistic-pagan contaminations.

In this study, dedicated to Gert Pelser as token of friendship and personal appreciation, I want to show, sharing as I do the concern not to isolate the Areopagus discourse from the rest of the book, how this speech is imbedded in the totality of the book. However, contrary to what is broadly argued in the literature on this speech, I want to demonstrate precisely this imbeddedness of the Areopagus speech by showing that in various other places Acts shares in the Hellenistic world of ideas about God in God's relationship to the world and people.

\footnotetext{
7 I hope that Löning knows that a few actual readers in antiquity like Justin and Clement of Alexandria have cherished and promoted precisely this idea.

8 See especially J Külling, Geoffenbartes Geheimnis: Eine Auslegung von Apostelgeschichte 17, 16-34, Zürich, 1993.

${ }^{9}$ See, among others, R Pesch, Die Apostelgeschichte, Zürich-Köln, II, 1986, 139.
} 


\section{2. "YET HE IS NOT FAR FROM EACH ONE OF US" (ACTS} 17:27)

When R Lane Fox describes the Hellenistic notions of epiphany in his highly recommendable book Pagans and Christians ${ }^{10}$, he begins with a reference to the scene in Acts which takes place in Lystra (14:8-20). After Paul has cured a cripple, the people shout, "The gods have come down to us in the likeness of men." They call Barnabas Zeus, and Paul the spokesman Hermes. This story narrates an epiphany of the gods in a style actually existent in Greek culture even from the time of the Homeric epics. You must be prepared for the possibility that God would manifest itself in human form; that a god would be standing in front of you who speaks to you encouragingly, cures you of a sickness, orders you to build an altar, speaks words of encouragement to you in difficult circumstances or saves you from misery and need. In all sorts of circumstances gods can reveal themselves and you must be careful not to antagonise them by lacking in respect.

The Lystra story is not unique to Acts. Something similar happens to Paul again when a viper bites his hands upon his arrival in Malta after being shipwrecked. The residents of Malta at first think that the goddess Justice has apparently not yet been appeased; but when Paul does not die, then they know for sure that he is a god (28:1-6). This is a misunderstanding similar to that experienced too by Peter in connection with the centurion Cornelius. When Peter enters his house, Cornelius wants to "worship him, falling down at his feet" (10:25). Peter then says to him: "Stand up; I too am a man." It is not permissible for people to be worshipped like God. If they, nonetheless, have this presumption - like Herod who lets the people cheer him with the words "the voice of a god and not of a man" (12:22) death invariably follows."

In reading Acts one must realise that Luke wrote his book in a culture that was unusually sensitive to the experience of the epiphanies of God. ${ }^{12}$ There are sacred places: sacred caves and springs where the nymphs live; sacred parks and temples that are consecrated to heroes and gods; there are sacred times that call for special sacrifices,

\footnotetext{
${ }^{10}$ London, 1986, 102.

"For this reason I think that these stories, in spite of the exegetes who claim the contrary, cannot be read as comic stories. People do make a mistake, but for the interlocutors, Peter and Paul, life itself is at stake.

12 See F Pfister, Epiphanie, in, Pauly-Wissowa Supplement 4, 277-323; E Pax, Epiphanie, in, Reallexikon für Antike und Christentum, V, 832-909.
} 
special clothes, attributes and processions; there are sacred objects that ask for worship: images and implements. The speech of Paul at the Areopagus relativizes all these realities: a temple cannot contain God; God is not needy, as if he would need something from us; God cannot be portrayed in objects of gold, silver or stone. And yet, in spite of this criticism, Paul also holds on to the belief in the nearness of God: for God is not far from each one of us. Is this a nearness in space or time? Can God or the divine manifest itself at any moment or in any form? Can we, blind as we are, nonetheless by groping perceive it when it touches us? Acts knows not only of stories about people having been mistaken in pointing out the divine by drawing the wrong conclusions, but also - and even more so - of stories telling positively about God's epiphanies. Heaven and earth are in close contact with each other. The heavenly becomes visible unremittingly and in various forms.

\section{THE EPIPHANIES OF THE ANGELS}

In the Asklepeion of Athens a relief has been found in which a male figure lies sleeping in bed. Hygieia and Asclepius stand on his right. The latter stretches out his hand to the patient. There are two servants who lay the man down on the bed (or lift him out of it). They could be the temple personnel. The man's dream and the actual reality in the temple of Asclepius would then correspond. However, the two men could also belong to the personnel of Asclepius himself and then assist him in the intricate operation. In this case, the man on the bed would then have a complex dream in which a number of divine persons appear and several miraculous events take place. ${ }^{13}$

From classical antiquity until well into the Middle Ages dreams and visions were the preferred places in which epiphanies happened. The book of Acts makes liberal use of them too. On the basis of classical dream theories, especially those of Artemidorus' Oreinocritica, E R Dodds has distinguished a number of dream types, which I now summarize under the following three headings. ${ }^{14}$ All three types of dreams are also used by Luke:

\footnotetext{
13 See F T van Straaten, Daikrates' Dream: A Votive Relief from Kos, and Some Other kat'onar Dedications, in, Bulletin van Antieke Beschaving 51, 1976, 1-38. The relief under discussion is printed as figure 7 and is described on page 3 .

14 The Greek and the Irrational, Los Angeles-London, 1951, 102-134.
} 


\subsection{The dream in the form of a familiar figure that speaks}

The dream consists of a visit by a (dream)figure, standing at the head of the bed, close to the head of the sleeper, who delivers a message from God. God speaks and says what the sleeper to do, but God does not show itself. The figure disguises himself or herself in the form of someone known to the sleeper - a friend, a girlfriend, a relative in Greek literature; an angel, a messenger of God in biblical literature. To us this is a peculiar form of dreaming, because in the real sense of the word, there is no dream. The visitor is a real figure that visits the sleeper in order to communicate to him or her an important message. The messenger often begins with the sentence: you are now asleep but when you wake up, you will remember me, and you have to carry out what I am now going to say. In Greek literature, the material figure itself has been the object of consideration: a figure that like a gust of wind sneaks in and out through the keyhole of the bedroom door. So Homer, in the Odyssey, narrates how Athena comes to visit Penelope in her sleep in the form of her sister Iphthime: "So into the chamber it passed by the thong of the bolt, and stood above her head, and spoke to her" $(\mathrm{Od} 4,802-03) .{ }^{15}$

Such a dream figure occurs in two places in Acts. In 9:12 it is related how Paul, at the same time that Ananias has a vision, himself sees Ananias in a vision: "Saul has seen a man named Ananias come in and lay his hands on him so that he might regain his sight." And in 16:6-10 it is recounted in what way Paul and his companions come to the decision to go across to Europe:

And they went through the region of Phrygia and Galatia, having been forbidden by the Holy Spirit to speak the word in Asia. And when they had come opposite Mysia, they attempted to go into Bithynia, but the Spirit of Jesus did not allow them; so, passing by Mysia, they went down to Troas. And a vision appeared to Paul in the night: a man of Macedonia was standing besecching him and saying, "Come over to Macedonia and help us." And

\footnotetext{
is See for example, also Od. 6,20/21, when Athens visits Nausikaa: "Like a breath of air the goddess sped to the couch of the maiden, and stood above her head, and spoke to her." In Mattew 1-2, the expression kat' onar is used several times: 'an angel of the Lord appeared in a dream to Joseph, saying', and then, the divine instructions which Joseph has to execute follow: to marry Mary, although she is pregnant; to fly to Egypt with mother and child; to go back to Israel and to Galilee. Dodds (p. 105) refers also to Acts 23:11 "The following night the Lord stood above his head (=Paul) and said, "Take courage...."
} 
when he had seen the vision, immediately he sought to go on into Macedonia, concluding that God had called us to preach the gospel to them.

It is an important turning point in the story of Acts and through all these manoeuvres and events the decision gets a rather special meaning.

\subsection{The dream as a vision of what is going to happen}

Artemidorus calls the foregoing dream form an oracle dream. Except for the figure that is sent by God itself, there are no images but only words. More in keeping with our own dream experiences is the visionary dream: a dream in which, as in a vision, one sees in advance what is going to happen in the future. The emphasis rests now on the seeing itself. Artemidorus gives as examples the following: "in this way someone at sea dreamed that he was shipwrecked, and in faci that is also what happened. For when he woke up, his ship sank and went under. He himself was saved with a few companions only with great difficulty. And another person dreamed that a man with whom he had organized a hunting party for the following day would wound him. And in fact he was wounded on the shoulder, on the very spot where he had dreamed it would happen."16

We are dealing here with predictive dreams which, because they directly predict the future, also have a sacred quality. This is possible, of course, in many ways. Sometimes there is practically an overlapping with the oracle dream. It is emphasized that you let yourself be led by God and use all the means available to find out what God wants from you.

The most detailed example in Acts is to be found in the conversion story of Cornelius and Peter in 10-11:17 "About the ninth hour of the day he saw clearly in a vision an angel of God coming in and saying to him, 'Comelius.' And he stared at him in terror and said, 'What is it, Lord?' And he said to him, 'Your prayers and your alms have ascended as a memorial before God. And now send men to Joppa and bring one Simon who is called Peter; he is lodging with Simon, a tanner, whose house is by the seaside."

\footnotetext{
${ }^{16}$ Oneirocritica 1.2.

17 P F Esler, Community and Gospel in Luke-Acts: The Sociological and Political Motivations of Lucan Theology, Cambridge, 1987, 94 points out that it is not through logical deduction that Peter comes to a conclusion but through the Holy Spirit who clarifies to him the meaning of the vision; D L Matson, Household Conversion Narratives in Acts: Pattern and Interpretation, Sheffield, 1996, 86-134 examines the connection between the spread of the Way and hospitality.
} 
All in all this vision is recounted four times in the short span of the subsidiary story: as a narrative in 10:3-6; as a message to Peter (10:22); as a story told by Cornelius to Peter (in 10:30-32); and within the story told by Peter to the believers in Jerusalem (11:13-14). The only time that some addition is made, is when Cornelius himself tells the story: "and behold, a man stood before me in bright apparel." As messengers of God, angels wear blazing white clothes. The vision itself is a mixture of past and future. It contains an order, which is rather easy to execute. Cornelius carries it out as asked of him by the angel. It brings about God's closer involvement with him and his family: the Spirit of God comes down upon them; they speak in tongues and glorify God. ${ }^{18}$

\subsection{The dream as a veiled message}

According to classical dream theory, a large number of dreams belong to yet another, totally separate category. The dreams that have been under discussion until now are dreams that give an insight into the future in straightforward language or in exact images. They are, however, the exception. A large number of dreams speak in veiled style. The images and the figures that are seen, speak about the future in an indirect way. To find out what the dream means, the dreamer (or the explainer of the dream) must translate the images into straightforward language. Artemidorus calls this type of dreams "allegorical dreams". ${ }^{19}$ It should be clear that we need here the philosophy of language: dreams as speech acts that evoke other speech acts.

The most detailed example in Acts is the vision that Peter receives in Joppe. It is

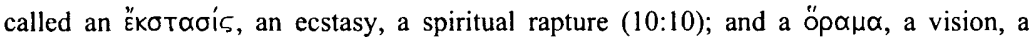
dream sight. Peter sees the heavens open and out of it comes a sheet with a number of clean and unclean animals in it. A voice resounds, telling Peter to eat. Three times Peter refuses. Aftenwards Peter is initially still in doubt as to the meaning of the vision, but when the people from Caesarea tell Peter about Cornelius and the order of the angel to invite him to Cornelius' house, Peter accepts the invitation. When he arrives at the

\footnotetext{
18 Another example is Acts 27:23 where Paul, aboard the ship which should transport him to Rome, tells the sailors: "For this very night there stood by me an angel of the God to whom I belong and whom I worship, and ise said, 'Do not be afraid, Paul; you must stand before Caesar ... So take heart, men ... But we shall have to run on some island."

${ }^{19}$ Oneirocritica 1.2 .
} 
house, he says that God has made it clear to him that no one may call any person profane or unclean (10:28). Divine approval is guaranteed by the outpouring of the Holy Spirit. Divine intervention thus happens on all levels: God gives a vision; God lets himself be heard within that vision; God sends messengers; God lets Peter respond in the right way; and God lets it be known when the right steps are taken. There is an intensive form of co-operation between heaven and earth.

This vision can serve as a transition to a still more surprising reality: the direct appearance of angels who sometimes also intervene directly in the natural state of affairs. In Acts, this distinction is once very explicitly put under discussion (12:7-11). Herod takes Peter as prisoner. Suddenly there appears an angel of the Lord over his head. The verb $\dot{\varepsilon} \tilde{\varepsilon} \sigma T \eta$ is a word that typically belongs to those dreams in which the sleeper receives a visit from someone known to him or her. The story thus begins as a dream story. Everything that follows afterwards could also happen in a dream. The angel wakes Peter, lets him get up, lets him put on his clothes - belt, sandals, and cloak everything narrated in sequence. During all these activities Peter is like someone who thinks he is seeing a vision: "And he went out and followed him; he did not know that what was done by the angel was real, but thought he was seeing a vision" (12:9). Only when the angel has brought him out in the street and suddenly has disappeared again, it is said, "and Peter came to himself, and said, 'Now I am sure that the Lord has sent his angel and rescued me.",20

Angels appear in visions but they can also intervene physically in human reality:

- 1:10: "Behold two men stood by them in white robes and said"

- 5:19: "But at night an angel of the Lord opened the prison doors and brought them (= the apostles) out and said"

- 8:26: "An angel of the Lord said to Philip"

\footnotetext{
20 Actually this concerns the classical distinction between övå and ürap (dream as opposed to reality) . See Od. 20, 90: "For this night again there lay by my (= Penelope's) side one like him (= Odysseus), and my heart was glad, for I believed it was no dream, but the truth at last"; see also Od. 19, 547.
} 
- 12:23: "Immediately an angel of the Lord smote him (= Herod)."

It is also an angel of God who, according to Stephen in his speech, has played an important role in the history of Israel.

- $7: 30,35:$ "an angel appeared to him in the wilderness of Mount Sinai in a flame of fire in a bush"

- 7:38: "the angel who spoke to him (= Moses) at Mount Sinai"

- 7:53: "you (= Israel) who received the law as delivered by angels"

As in the history of Israel, so also now again angels are actively involved in carrying out God's plan for humankind.

What is for me most surprising in the narrative is the fact that the people involved find this appearance totally matter-of-course. This is an indication that people (the characters in the story, as well as the supposed readers) carry on a form of intimacy with the heavenly which gives Acts a very specific, religious colour.

\section{THE EPIPHANIES OF JESUS}

Sophocles' tragedy Ajax opens with a scene in which Odysseus, like a hunter, tracks footprints in the sand to find out who has slaughtered the cattle captured by the Greeks in the fight against the Trojans. Without seeing her, he is in contact with Athena. She speaks to him and tells him what Ajax has done "voice of Athena, Goddess most by me beloved, how clearly, though I see thee not, those accents strike my ear and thrill my soul" (Ajax 14.15). Among theatre and tragedy experts the question is asked whether Athena is perhaps visible to the public, in the form of a bird or of the Athenian cult statue. $^{22}$ In any case, sight of Athena is denied Odysseus, but not her voice. Ajax himself has not even heard her voice but all the same he is under her influence. Athena has

\footnotetext{
${ }^{21}$ See also 23:8,9 where the Pharisees say of Paul: "What if a spirit or an angel spoke to him?"

22 See especially H Musurillo, The Light and the Darkness: Studies in the Dramatic Poetry of Sophocles, Leiden, 1967; R W Burton, The Chorus in Sophocles' Tragedies, Oxford, 1980, and D Seale, Vision and Stagecraft in Sophocles, London, 1982.
} 
driven him beside himself and while Ajax intended to capture, punish and kill the leaders of the Greeks - Agamemnon, Menelaus, and Odysseus - he has been at it only with the cows, calves and sheep. Heavenly epiphanies sometimes have a terrible impact.

When Saul is on the road to Damascus to arrest the followers of the Way and to bring them to Jerusalem, an epiphany comes over him which demonstrate close parallels to the revelation of God just described. It is an experience of God, which has great consequence for the rest of the story. It is a real irruption of the divine into human reality. The mode itself too exhibits certain parallels. Saul is suffused with light; he hears a voice but sees no one or in any case cannot see who it was; he gets to hear whose voice it is and receives an order. ${ }^{23}$

In the first version of this story his travel companions hear the voice but do not see who it is (9:7; neither does Saul!) In the second version they do see the light but they don't hear the voice (22:9). In the third version the story of Ananias is omitted totally and nothing more is said about the reaction of the travel companions. These are variants of the story of which one evidently should not make too much.

Indirectly, Saul had presumably already experienced a Jesus epiphany. For it seems reasonable to assume that Paul was present when Stephen held his big speech before the Sanhedrin, "and his face was like the face of an angel" (6:15). At the end of his speech it was given to Stephen that the heavens opened for him, "and he saw the glory of God, and Jesus standing at the right hand of God." That is what he also proclaims loudly, "Behold I see the heavens opened, and the Son of man standing at the right hand of God" $(7: 55,56)$.

These Jesus epiphanies have a big impact and allure. They are, quite obviously, ${ }^{24}$ of another order than the Jesus epiphanies with which the book begins: the forty days during which Jesus stays with his apostles after his death. This going about of Jesus with his disciples is, in fact, presented so naturally that one tends to forget that this contact

\footnotetext{
${ }^{23}$ K Löning, Die Saulustradition in der Apostelgeschichte, Münster, 1973, 61-97 examines thoroughly the possible parallel texts in $2 \mathrm{Macc} 3$ and in Joseph and Aseneth.

24 The differences between the two types of stories are great. The appearance stories from the forty-day period tell about a much more human Jesus. Some exegetes conclude from this that for Luke Jesus is placed by God at his right-hand not immediately after his resurrection but only after his assumption into heaven; see in particular G Lohfink, Die Himmelfahrt Jesu: Untersuchungen zu den Himmelfahrts- und Erhöhungstexten bei Lukas, München, 1971, 272.
} 
happens after the death of Jesus. It is indeed a privileged time (only certain persons get to see Jesus): "God raised him from the dead; and for many days he appeared to those who came up with him from Galilee to Jerusalem" (13:31; cf. 10:41) - but at the same time it has something matter-of-course: Jesus shows himself to them (orrávoual -1:3); he talks with them $(1: 3,7-8 ; 10: 41-42)$; and - most surprisingly - he eats with them:

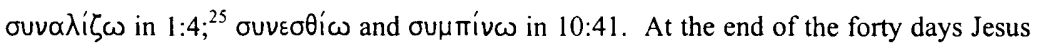
is taken up into heaven, an event that evokes some biblical as well as many Hellenistic stories about the ascent to heaven of great religious figures. Jesus is now bound to heaven and he has and will exercise his influence from heaven.

Paul is influenced most directly by the heavenly Jesus. He is granted the most impressive Jesus epiphany, as just elaborated upon, but it is to Paul also that Jesus appears a number of times in a dream:

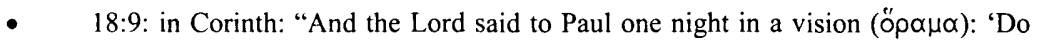
not be afraid but speak and do not be silent etc."'

- 22:17: in the temple of Jerusalem, immediately after his return from Damascus, Paul undergoes an ह̌koraoıs in which the Lord appears to him again and, in a rather long conversation, speaks words of encouragement to Paul and gives him the mission to go to the nations.

- 23:11: when Paul is in prison, the Lord comes to him in the night and stands above his head, at the head of his bed, and encourages him again. ${ }^{26}$

What is granted to other people is much more indirect. The people experience the power, the presence and the closeness of the heavenly Jesus not in a direct Jesus epiphany but through the use of his name. Peter anticipates this on Pentecost day, in his address to the people after the coming of the Spirit. He cites Joel 3:1-5, which ends with the sentence: "And it shall be that whoever calls on the name of the Lord shall be saved" (Acts 2:21).

\footnotetext{
${ }^{25}$ Whether this can have this meaning, see the commentaries. Barrett, Acts I, $71 \mathrm{f}$, examines thoroughly the more literal meaning "to cat salt".

${ }^{26}$ Only one other time does the Lord appear in a vision to someone other than Paul, namely to Ananias (in $9: 10$ ). But that vision takes place in the story of the epiphany to Saul on the road to Damascus.
} 
The name of God in Joel has become in Acts the same as the name of Jesus: the Name of Jesus as a source of power, already experienced and still to be experienced. ${ }^{27}$

In the chapters of Acts (3-5) that immediately follow, this is recounted extensively enough. Peter cures the cripple in the Name of Jesus $(3: 6,16)$. By virtue of this cure Peter and John are put behind bars and interrogated by the Sanhedrin: "by what power or by what name did you do this?" (4:7) It is a question that gives Peter the opportunity to profess in an even grander manner that the Name of Jesus has a saving power, not only for the sick but for everyone who believes in this name $(4: 10,12)$. This brings the Sanhedrin to forbid Peter and John to undertake anything else in this Name $(4: 17,18)$, a prohibition that naturally is not followed. The entire community goes to pray for miracles in the Name of Jesus $(4: 30)$. It is a prayer that is answered $(5: 12-16)$ and as a result leads to new persecutions. The whole group of the apostles is now put in prison and forbidden to do anything else in the Name of Jesus $(5: 28,40)$. This leads to only greater joy among the apostles: "then they left the presence of the council, rejoicing that they were counted worthy to suffer dishonor for the name" $(5: 41){ }^{28}$

The Name of Jesus is a power that leads to salvation. The Name of Jesus is pronounced at baptism over those who are prepared to follow the Way. It is said several times that people are baptized "in the Name of Jesus": in Jerusalem (2:38), in Samaria (8:16); at the house of Cornelius and his family as the first non-Jews $(10: 43,48)$; as prophecy for the nations (15:17); and among the followers of Apollos in Ephesus, twelve in number (19:5).

The story of the conversion of Paul is paradigmatic. He persecutes the people who invoke the Name $(9: 14,21 ; 26: 9)$ but on his way to propagate the Name among the nations he himself will suffer a lot $(9: 16)$. He has to let himself be baptized in the Name of Jesus (22:16); he does this, too (9:8), and then acts openly in the Name of Jesus, even immediately in Damascus (9:27), but also in Jerusalem (9:28), in Antioch (11:26) and afterwards in all the places he sought out.

\footnotetext{
${ }^{27}$ For a number of Hellenistic parallels, see P W van der Horst, "Hellenistic Parallels to Acts (Chapter 3 and 4)," in, P W van der Horst \& G Mussies, Studies on the Hellenistic Background of the New Testament, Utrecht, 1990, 145.

${ }^{28}$ See also Acts 8:12f,16 where a connection is made between the Name of Jesus, baptism and miracles.
} 
The Name of Jesus, symbol of the Jesus who sits at the right hand of God in heaven, is the point of reference. ${ }^{29}$ Whoever does the right thing with this Name, receives a special power as Paul shows in Philippi, when he expels in the Name of Jesus the spirit of divination from the slave girl. But whoever does this in a wrong way suffers great harm for himself, as appears from the story about Simon Magus in Acts 8 and from the story about the Jewish exorcists in Ephesus in Acts 19:13-17

Through the Name of Jesus, the followers of the Way who are called Christians already in a very early phase of the movement $(11: 26)$, are connected with the heavenly Jesus. The Name of Jesus is their guiding light that will save them as far as death and beyond.

\section{THE EPIPHANIES OF GOD}

When the messenger in Euripides' tragedy The Bacchae ${ }^{30}$ has told the exciting story about what all the bacchantes - the mothers and daughters of Thebes - have undertaken and are undertaking on the mountain, there is again a conversation between the foreigner - the man from Asia who visits Thebes - and Pentheus, the ruler who has recently succeeded his giandfather Cadmus as monarch. But it is only too clear from the conversation that the recent, strange events have not been happening without his knowledge. Pentheus has already put the foreigner in prison, but only for a short time. The stranger has mocked Pentheus. He has assumed the form of a bull, but in the meantime he has watched from a distance how Pentheus did his best to tie the bull. Through an earthquake he has reduced the entire palace to ruins. Fire has started at the monument of Semele, the mother of Dionysus.

And still Pentheus thinks that he can say to the strange man (Dionysus in disguise), - "Don't lecture me. Be glad that you have escaped the chains; otherwise I will punish you once again" (Bacchae 792-93). It is at this point that Dionysus says to

\footnotetext{
${ }^{29}$ P W van der Horst, "Hellenistic Parallels to Acts (Chapter 3 and 4)," in P W van der Horst \& G Mussies, Studies on the Hellenistic Background of the New Testament, Utrecht, 1990, 145 refers to the countless magical papyri in which the use of the god's or spirit's name is terribly important.

30 For the interpretation of this tragedy, see, besides the more general works on Euripides, E R Dodds, Euripides ' Bacchae, Oxford, 1960/2 [1944]; R P Winnington-Ingram, Euripides and Dionysus: An Interpretation of the Bacchae, Amsterdam, 1969; J Roux, Euripide: Les bacchantes, Vol 1-2, Paris, 1970; H Oranje, Euripides' Bacchae: The Play and its Audience, Leiden, 1984; Ch Segal, "The Bacchae as Metatragedy," in P Burian (ed), Directions in Euripidian Criticism: A Collection of Essays, Durham, 1985, 156-176; A Rijksbaron, Grammatical Observations on Euripides 'Bacchae, Amsterdam 1991.
} 
him: "I would rather bring him (=Dionysus) offerings than, as victim, a mortal in combat with God, kick against the goads" (Bacchae 794-95).

It is this last sentence which is said by Paul in his speech before Festus and Agrippa. - Jesus too has said in Hebrew to Saul: "Saul, Saul, why do you persecute me? It is stubborn to kick against the goads" (26:14). Saul, too, resists God's plans. He takes people prisoner. He has - together with others - condemned them to death. By means of torture he has attempted to force them to blaspheme. He has pursued them even outside their own country: "breathing threats and murder" 31 is how the author of Acts has summarized his behavior much earlier in the story $(9: 1)$.

Acts $26: 14$ is an allusion, almost a quotation even. It is a sort of proverb; ${ }^{32}$ the tragedy Bacchae was still very well known then. ${ }^{33}$ Moreover, the text is imbedded in a multitude of parallel references:

- Dionysus is seen as Yóns, a magician-fraud (Bacchae 234) (cf. the discussion around Simon Magus in Samaria in Acts 8:9-25 and around Bar-Jesus in Cyprus in Acts 13:4-12);

- Dionysus causes an earthquake (Bacchae 580ff); this has a parallel in the events in the prison of Philippi (Acts 16:25-35)

- $\quad$ There is also a release from prison (Bacchae 440), just as with Paul and Silas in Philippi (Acts 16:25-35), the apostles in Jerusalem (Acts 5:19-21) and Peter (Acts 12:4-10);

- But above all there is the prevalence of the word $\theta \varepsilon O \mu \alpha \chi \varepsilon \dot{\varepsilon} \omega$ in Bacchae 45; 325; $635 ; 1254 / 55$ and the references in Acts.

In Acts 4 and 5 in the discussions which at first only Peter and John, but later the apostles as a group have with the Sanhedrin, this "struggle against God" plays a central role.

\footnotetext{
31 For the Hellenistic imbedding of this expression, see $P$ W van der Horst, "Breathing threats and murder ... The Hellenistic Background of Acts 9:I", in P W van der Horst \& G Mussies, Studies on the Ilellenistic Background of the New Testament, Utrecht, 1990, 164-176.

32 The text is also used in other contexts. See Aeschylus, Agamemnon 1624; Pindar, Pythian 2, 95.

33 See on the papyri, E R Dodds, Bacchae, Oxford, 1960, Ivi-lix; E B Donovan, Euripides Papyri, I: Texts from Oxyrhynchus, New Haven-Toronto, 1969; J Roux, Euripide: Les bacchantes, Paris, 1970, 91-93.
} 
Peter and John answer the Sanhedrin: "Whether it is right in the sight of God to listen to you rather than to God, you must judge" (4:19), and in 5:29 Peter and the apostles say, "We must obey God rather than men." ${ }^{34}$ In the speech of Gamaliel to the Sanhedrin even the word $\theta \varepsilon o \mu \alpha$ ' $\chi 01$ is used: "You might even be found opposing God."

One must not put up any barriers against what God is planning to do with people; on the contrary, one must let oneself be guided by it. A central word in this context is

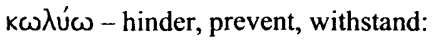

- 8:36: in the conversation between Philip and the Ethiopian eunuch: "See, here is water! What is to prevent my being baptized";

- 10:47: Peter on baptizing the family of Cornelius: "Can any one forbid water for baptizing these people who have received the Holy Spirit";

- 11:17: Peter to the brethren in Jerusalem on baptizing non-Jews: "Who was I that I could withstand God?"

Finally, it has already been remarked very often that Acts, not without reason,

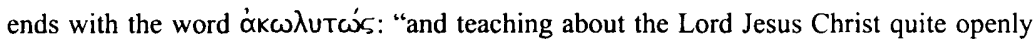
and unhindered" (28:31).

There is a close connection between this clearing the way for God and the sensitivity to the Holy Spirit. The Spirit of God leads people and makes them follow the correct way. The Spirit is also the modality in which God lets himself bè experienced. It is in Luke's view also the only form which makes God "epiphan". This appears most clearly perhaps from a story in Luke, that of the announcement by the angel of the birth of Jesus. If one is ever going to speak of an epiphany of God, then it has to be with reference to this story. But even there it is at best a promise which will happen in the future, and then still in a modality that is very much toned down: "The Holy Spirit will come upon you, and the power of the Most High will overshadow you" (Luke 1:35) - the pneuma and the dynamis of God in the form of the shadow of a cloud. I suppose that the opening verse of the Magnificat refers to this carefulness of God. God did not show himself in his glory

\footnotetext{
34 These sentences relate to the well known Antigone- and Socrates motif. See Barrett, Acts I, 237 and 289: "Peter's application ... is new and shocking because it sets over against each other God and those men who were best qualified to expound God's command as expressed in his law."
} 
and majesty - for that would have led to the death of Mary - but only in a disguise. Mary says: "My spirit rejoices in God, my Savior, for he has regarded the low estate of his handmaiden" (Luke 1:47, 48). God has saved Mary; he has regarded kindly her littleness, that is that she, like all of us, was but a human being.

Taking as comprehensive a view as possible, I can say that this presentation of issues is correct, in any case for Acts. It is only Abraham, it is said in the opening sentence of the speech of Stephen, who has seen the God of glory. ${ }^{35}$ Of no one else has this been said yet: not of Moses, not of Stephen, nor of Paul. The presence of God is always mediated: by dreams, visions; by angels; by the name of Jesus, as we have seen, but also and in a very special way "by the power of the Holy Spirit" (see Acts 1:8).

This is, of course, not the place to put under discussion the complete pneumatology of Luke. What is now relevant is to assert that the Spirit of God - sometimes called "Spirit of Jesus" (Acts 16:7), because he is poured out over people in this powerful form through the intercession of Jesus $(1: 4,8)-$ is a power which affects people, gives them strength in all sorts of difficulties, makes them go all over the world, and can come in totally unexpected moments, and then taking on many forms.

In these last considerations I return, in a way, to the questions I asked at the beginning of this article: is the nearness of God nearness in space or time? Can God or the divine manifest itself at any moment or in any form? Can we, being blind, still perceive it, by groping, when it touches us? The Pentecost story is, obviously, the prototype: the storm, the fire, the tongues of fire; the speaking in other tongues; the fulfilment of the prophecy of Joel (Acts 2). It is an event that repeats itself on a smaller scale a number of times:

- $\quad$ in $4: 31$ when the group is praying and when the place where they are gathered shakes;

- in 8:17 when Peter and John lay their hands on the Samaritans and they receive the Spirit;

35 In Acts 7:3 it looks as if something similar is also said of Stephen, but what is written about him (in 7:55) is not that he has seen God ("the God of glory") but that he has seen "the glory of God" (7:55). 
- in 9:17 when Ananias lays his hands on Paul so that he from that moment on becomes the proclaimer of the Messiahship of Jesus;

- in 10:44 with the family of Cornelius who also go on to speak in tongues (see also $10: 45,47 ; 11: 15,16 ; 15: 8)$;

- in 19:1-6 with the disciples of Apollo in Ephesus who also go on to speak in tongues and to prophesy.

It is said of all sorts of people that they "are filled with the Spirit" and that this Spirit gives them the power to perform their courageous, surprising and open-hearted deeds: the deacons in 6:1-6; Stephen in a special way; Paul naturally (13:9), but also the people who accompany him, Barnabas (11:24) and his disciples (13:52), Apollos (18:25) and Agabus, the prophet $(11: 28 ; 21: 4)$.

For the Spirit of God is, after all, very actively involved in the well-being of the community of God: he puts the words in Stephen's mouth (Acts 7); he catches Philip away after he has baptized the eunuch (8:39); he speaks to Peter when he is still puzzling over the strange vision $(10: 19 ; 11: 12)$; he lets Agabus foretell the famine (11:28); he speaks to the community in Antioch and chooses Barnabas and Paul for their travels $(13: 2,4)$; he stops Paul on his journey in the north of Asia and leads him and his companions to Europe $(16: 6,7)$; he constrains Paul to go back to Jerusalem and assures him that he will have to suffer much $(20: 22,23)$, and in Caesarea, finally, Agabus announces to Paul what the Spirit has let him know about Paul $(21: 11)$.

In Luke's view the pneuma is connected with matter one way or another. It is a powerful fluid, a sort of ether perhaps. ${ }^{36}$ The Spirit is wind, is fire; the Spirit influences the speech of people; he makes them speak in tongues; and he makes them speak openheartedly. The Spirit is the power which gives people the courage to bear suffering on account of Jesus, the Messiah; it is a physical force which causes earth-quakes; a power which sets people on long journeys, but also physically restrains them. It gives life and withholds life. The Spirit is a power which surrounds people: in him we live, and move, and have our being. He lets himself be experienced, often also very unexpectedly. God

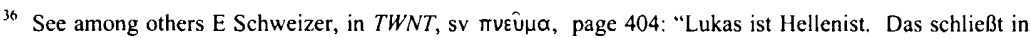
sich, daß er sich Kraft nur in der Form der Substanz vorstellen kann."
} 
Acts 17:27 - "That they might feel after him and find ..."

is very near to man. At any moment and in various modalities he lets his presence be experienced by people who, although they are blind and cannot see God, are still gropingly searching for him. 